\title{
Mimical Reconstruction And Aesthetic Repair of The Nail After Resection of Subungual Melanocytic Nevus
}

\author{
Wenpeng $\mathrm{Xu}$ \\ Second Hospital of Shandong University \\ Xiucun Li \\ Second Hospital of Shandong University \\ Songhua Cao \\ Second Hospital of Shandong University

\section{Ning Zhang} \\ Second Hospital of Shandong University \\ Yong Hu ( $\checkmark$ handsurgeon@163.com ) \\ Second Hospital of Shandong University
}

\section{Research Article}

Keywords: Mimical reconstruction, aesthetic repair, subungual melanocytic nevus, nail

Posted Date: November 3rd, 2021

DOI: https://doi.org/10.21203/rs.3.rs-279289/v2

License: (c) (1) This work is licensed under a Creative Commons Attribution 4.0 International License. Read Full License

Version of Record: A version of this preprint was published at BMC Surgery on December 1st, 2021. See the published version at https://doi.org/10.1186/s12893-021-01423-9. 


\section{Abstract}

Background: The purpose of this study is to report the outcomes of mimical reconstruction and aesthetic repair of the nail.

Methods: When the width of the pigmented bands was more than $1 / 2$ of the whole nail width, the mimical reconstruction of the nail, the lateral toe pulp island flap covered the wound via the subcutaneous channel, was performed. If the width of the pigmented bands ranged from $1 / 4$ to $2 / 5$ of the entire nail, the aesthetic repair of the nail, the split-thickness excision under microscope, would be carried out.

Results: The average age at the time of surgery was 14.5 years. The lesions were located at the toes in 5 patients and fingers in 3 patients. No complications occurred postoperatively. In 5 patients with the mimical reconstruction of the nail, all of toenail showed well-settled flap. In three patients with the aesthetic repair of the nail, there was no nail malnutrition or deformity, and all nails have an aesthetic appearance.

Conclusions: Mimical reconstruction and aesthetic repair of the nail following resection of subungual melanocytic nevus is reliable and feasible. It seems to be satisfactory that "like tissue" repairs the complex nail defects. All patients obtain an excellent aesthetic outcome.

\section{Level of Evidence: V}

\section{Introduction}

Melanocytic nevi are benign tumor arising from the proliferation of melanocytes resulted from the BRAF(v-raf murine sarcoma viral oncogene homolog B1)-activating mutations caused by various etiology such as ultraviolet light, unidentified environmental mutagens ${ }^{[1]}$. Subungual melanocytic nevi, also known as melanonychia ${ }^{[2]}$, are as a result of the proliferation of melanocytes in the nail matrix and nail bed ${ }^{[3]}$, being usually junctional nevi and rarely compound nevi ${ }^{[4,5]}$.

According to the diagnostic criteria of the subungual melanoma ${ }^{[2,6]}$ and the consensus on melanonychia nail plate dermoscopy ${ }^{[7]}$, surgical resection of the subungual melanocytic nevi was performed when the width of the subungual pigmented bands is greater than $3 \mathrm{~mm}$. If subungual melanocytic nevi are not resected, there will be a risk of malignant transformation ${ }^{[8,9]}$. Also, they also cause great mental stress to the patient. Previous studies have shown about $25 \%$ - $33 \%$ of cutaneous melanomas result from melanocytic nevi ${ }^{[8,9]}$, whereas this rate in high-risk patients such as those with many nevi is possibly as high as $54.2 \%{ }^{[10]}$. The Clarke model of melanoma pathogenesis assumes that the evolvement process from normal melanocytes to melanoma may experience the four stages of banal nevi, dysplastic nevi, melanoma in situ, and invasive melanoma, which is usually consider to be driven by the gradual accumulation of pathogenic genetic/epigenetic changes ${ }^{[1,11,12]}$. However, some evidence suggests that the progression in most melanomas is much more intricate and covers numerous different paths, which may be partly determined by different carcinogenic hits ${ }^{[13]}$.

Currently, there are no consensus on treatment of the subungual melanocytic nevi with the pigmented band width > $3 \mathrm{~mm}$. For the subungual melanocytic nevi with the pigmented band width of 3 to $6 \mathrm{~mm}$, transverse elliptical matrix excision or releasing flap method or tangential matrix excision was performed ${ }^{[2,14]}$. For the subungual melanocytic nevi with the pigmentation on lateral one-third of nail, lateral longitudinal excision was carried out ${ }^{[2]}$. For the subungual melanocytic nevi with the pigmentation on the whole nail, the whole nail was resected and then the 
wound was covered by skin grafts, fillet flap with the phalanx shortening, and free flap ${ }^{[2,15-17]}$. Importantly, these options change post-operative nail appearance and cannot obtain a well aesthetic outcomes. To maintain the aesthetic contour of the nail, the methods of mimical reconstruction and aesthetic repair of the nail were performed in patients with the subungual melanocytic nevi. Thus, the purpose of this study is to report the outcomes of mimical reconstruction and aesthetic repair of the nail.

\section{Patients And Methods}

\section{Inclusion and exclusion criteria}

This clinical retrospective study was approved by the Research Ethical Committee of the Second Hospital of Shandong University (KYLL-2021(LW)017). Written informed consent was obtained from each patient. All methods were performed in accordance with the declaration of Helsinki - ethical principles for medical research involving human subjects. In our series, inclusion criteria of the patients with the subungual pigmented lesion were given below: (1) more than $3 \mathrm{~mm}$ or $1 / 4$ of the whole nail of the pigmented bands width, (2) dark brown to black color, (3) greater than one year interval from onset to surgical resection, (4) progressive increasing in pigmented bands width within one year, (5) presence or absence of pigmentation on the adjacent skin (Hutchinson's sign). The patients who presented with the broad bands of pigment $<3 \mathrm{~mm}$, or blurred surrounding borders, or nail dystrophy and/or ulceration were excluded in this study. Accordingly, we reviewed hospital medical records from August 2013 to September 2020, and found that 8 patients underwent the mimical reconstruction and aesthetic repair of the nail following the nail resection, and were diagnosed as the subungual melanocytic nevus by pathology.

\section{Microsurgical technique}

Based on the width of the pigmented bands, two different microsurgical methods were selected. When the width of the pigmented bands was more than $1 / 2$ of the whole nail width, the mimical reconstruction of the nail was performed, namely, the lateral toe pulp island flap covered the wound via the subcutaneous channel following the resection of the whole nail. If the width of the pigmented bands ranged from more than $3 \mathrm{~mm}$ or $1 / 4$ of the whole nail to $2 / 5$ of the whole nail, the aesthetic repair of the nail, the split-thickness excision of the pigmented nail matrix and nail bed lesions under microscope, would be carried out.

\section{Mimical reconstruction of the nail}

The mimical reconstruction of the nail was defined as the reconstruction of the nail using the lateral toe pulp island flap after the resection of the whole nail. After removing the nail plate, the whole nail bed including germinal matrix and sterile matrix was resected. Also, the whole nail folds were kept intact during resection of the nail bed (Fig. 1A). Lateral toe pulp island flap based on the plantar digital artery was design according to the size of the total nail bed (Fig. 1B). A rhombic incision was made. Flap was dissected from the distal to the proximal side, including the plantar digital nerve (Fig. 1C). The flap was transferred to the defect region of the nail bed via the subcutaneous channel (Fig. 1D), and covered the wound (Fig. 1E). Finally, the flap donor site was closed primarily.

\section{Aesthetic repair of the nail}

The aesthetic repair of the nail was regarded as the split-thickness excision of the pigmented nail matrix and nail bed lesions under microscope (Video 1). After removing the nail plate, the origin and location of the pigmented lesions of the nail was identified. The longitudinal incision was made at the junction of the proximal nail fold and pigmented lesions (Fig. 2A). The pigmented lesions of the nail matrix and nail bed was exposed thoroughly. The 
oblique incision was made proximally and bilaterally on the lesions, respectively. The excisional split-thickness nail matrix and nail bed was designed according to the lesion size under the microscope (Fig. 2B). The nail matrix and nail bed lesion were completely removed under the microscope. In other words, the nail matrix and nail bed invaded by the lesion was completely removed, and the uninvaded nail matrix and nail bed was kept. The invaded superficial half of the nail matrix and nail bed depth was removed under the microscope (Fig. 2C). Finally, the residual nail bed was flatted under the microscope (Fig. 2D). The incision at the proximal nail fold was sutured.

\section{Post-operative Management}

Post-operative care and monitoring were performed for the first two post-operative days. No anticoagulant was used. Patients were ambulated on the third post-operative day but were instructed to avoid any strenuous exercise for two weeks. The skin sutures were removed at post-operative two weeks.

\section{Results}

Of eight patients, two patients were females and six patients were males. The average age at the time of surgery was 14.5 years (range, 1 to 41 years). The mean interval from onset to surgical resection was 2.9 years (range, 1 to 5 years). The lesions were located at the toes in 5 patients and fingers in 3 patients. In five out of 8 patients, the width of the pigment bands was more than $1 / 2$ of the nail width. Among them, five patients underwent the mimical reconstruction of the nail. In addition, the aesthetic repair of the nail was carried out in 3 patients. The basic information of the ten patients with the subungual melanocytic nevus was shown in Table 1.

No complications such as wound infection, wound dehiscence, nail bed and/or fold necrosis, flap necrosis occurred postoperatively. Eight patients were followed up, and the follow-up time ranged from 5 months to 55 months (mean, 19.6 months). There was no hypertrophic scar at the incision wound. In 5 patients with the mimical reconstruction of the nail, all of toenail showed well-settled flap; these five patients can wear shoes and walk normally, and were satisfied with the outcomes. Moreover, in three patients with the aesthetic repair of the nail, there was no nail malnutrition, recurrence or deformity, and all nails have an aesthetic appearance. Finally, all patients (8 patients) obtained a satisfactory outcome.

Table 1. The basic information of the eight patients with the subungual melanocytic nevus. 


\begin{tabular}{|c|c|c|c|c|c|c|c|c|c|}
\hline Patient & Sex & $\begin{array}{l}\text { Age } \\
\text { (Years) }\end{array}$ & $\begin{array}{l}\text { Interval } \\
\text { from } \\
\text { onset to } \\
\text { surgical } \\
\text { resection } \\
\text { (years) }\end{array}$ & Laterality & Site & $\begin{array}{l}\text { Width } \\
\text { of } \\
\text { pigment } \\
\text { bands }\end{array}$ & $\begin{array}{l}\text { Colours } \\
\text { of } \\
\text { pigment } \\
\text { bands }\end{array}$ & $\begin{array}{l}\text { Hutchinson's } \\
\text { sign }\end{array}$ & Treatment \\
\hline 1 & $M$ & 13 & 4 & $\begin{array}{l}\text { Right } \\
\text { foot }\end{array}$ & $\begin{array}{l}\text { Great } \\
\text { toe }\end{array}$ & $\begin{array}{l}\text { More } \\
\text { than } \\
1 / 2 \text { of } \\
\text { the } \\
\text { whole } \\
\text { nail } \\
\text { width }\end{array}$ & Black & No & MR \\
\hline 2 & $M$ & 4 & 4 & $\begin{array}{l}\text { Right } \\
\text { foot }\end{array}$ & $\begin{array}{l}5^{\text {th }} \\
\text { toe }\end{array}$ & $\begin{array}{l}\text { The } \\
\text { whole } \\
\text { nail }\end{array}$ & $\begin{array}{l}\text { Dark } \\
\text { brown }\end{array}$ & No & MR \\
\hline 3 & $\mathrm{~F}$ & 41 & 3 & $\begin{array}{l}\text { Right } \\
\text { foot }\end{array}$ & $\begin{array}{l}4^{\text {th }} \\
\text { toe }\end{array}$ & $\begin{array}{l}\text { More } \\
\text { than } \\
1 / 2 \text { of } \\
\text { the } \\
\text { whole } \\
\text { nail } \\
\text { width }\end{array}$ & $\begin{array}{l}\text { Dark } \\
\text { brown }\end{array}$ & No & MR \\
\hline 4 & $M$ & 3 & 2 & Left Foot & $\begin{array}{l}4^{\text {th }} \\
\text { toe }\end{array}$ & $\begin{array}{l}\text { The } \\
\text { whole } \\
\text { nail }\end{array}$ & $\begin{array}{l}\text { Dark } \\
\text { brown }\end{array}$ & No & MR \\
\hline 5 & $\mathrm{~F}$ & 5 & 2 & $\begin{array}{l}\text { Right } \\
\text { foot }\end{array}$ & $\begin{array}{l}5^{\text {th }} \\
\text { toe }\end{array}$ & $\begin{array}{l}\text { The } \\
\text { whole } \\
\text { nail }\end{array}$ & Black & No & MR \\
\hline 6 & $M$ & 1 & 1 & $\begin{array}{l}\text { Right } \\
\text { hand }\end{array}$ & $\begin{array}{l}\text { Index } \\
\text { finger }\end{array}$ & $\begin{array}{l}\text { About } \\
1 / 4 \text { of } \\
\text { the } \\
\text { whole } \\
\text { nail } \\
\text { width }\end{array}$ & Black & No & AR \\
\hline 7 & $M$ & 19 & 5 & $\begin{array}{l}\text { Left } \\
\text { hand }\end{array}$ & $\begin{array}{l}\text { Little } \\
\text { finger }\end{array}$ & $\begin{array}{l}\text { About } \\
2 / 5 \text { of } \\
\text { the } \\
\text { whole } \\
\text { nail } \\
\text { width }\end{array}$ & $\begin{array}{l}\text { Dark } \\
\text { brown }\end{array}$ & No & AR \\
\hline 8 & $M$ & 30 & 2 & $\begin{array}{l}\text { Left } \\
\text { hand }\end{array}$ & $\begin{array}{l}\text { Index } \\
\text { finger }\end{array}$ & $\begin{array}{l}\text { About } \\
1 / 3 \text { of } \\
\text { the } \\
\text { whole } \\
\text { nail } \\
\text { width }\end{array}$ & $\begin{array}{l}\text { Dark } \\
\text { brown }\end{array}$ & No & AR \\
\hline
\end{tabular}

M: male. F: female. MR: Mimical reconstruction of the nail bed. AR: Aesthetic repair of the nail bed.

\section{Case 1 (Patient 1)}

A 13-year-old male patient had a history of progressive subungual melanosis for over 4 year in the hallux of right foot but not pseudo-Hutchinson sign (Fig.3A). After the resection of the tumor, it was pathologically diagnosed as 
the subungual melanocytic nevus. The defect of the nail matrix was reconstructed using the lateral toe pulp island flap based on the plantar digital artery (Fig.3B and 3C). The patient was followed up for 16 months and made a well recovery after surgery (Fig.3D, 3E and 3F).

\section{Case 2 (Patient 5)}

A five-year-old female patient had a history of progressive subungual melanosis for greater than two years and intermittent pain for more than half a year in the fifth toe of right foot (Fig.4A). After the resection of the tumor (total nail matrix), it was pathologically diagnosed as the subungual melanocytic nevus of the fifth toe. The defect of the total nail matrix was reconstructed using the lateral toe pulp island flap based on the plantar digital artery (Figs.4B and 4C). The patient was followed up for 5 months and obtained a satisfactory outcome (Figs.4D and 4E).

\section{Case 3 (Patient 6)}

The subungual melanocytic nevus of the index finger of the right hand was pathologically diagnosed in a 1-year-old boy (Fig.5A). It had a history of progressive subungual melanosis for over half a year. After removing the nail plate, the split-thickness excision of the pigmented nail bed lesions under microscope was performed (Fig.5B and 5C). Also, the residual nail bed was flatted under the microscope (Fig.5D). The patient was followed up for 20 months and gained a satisfactory outcome (Fig.5E).

\section{Discussion}

In this study, the technique on mimical reconstruction and aesthetic repair of the nail following resection of subungual melanocytic nevus is a reliable and feasible, all patients obtained a satisfactory appearance.

Although melanocytes are the normal pigment-producing cells in the skin ${ }^{[1]}$, the density of melanocytes in the nail matrix $\left(200 / \mathrm{mm}^{2}\right)$ and nail bed (absent to $\left.50 / \mathrm{mm}^{2}\right)$ is much smaller than in normal skin $\left(1150 / \mathrm{mm}^{2}\right){ }^{[3,5]}$. These also explains why some of subungual melanocytic nevi tend to be not black. Therefore, it is not reliable to evaluate the malignant degree of pigmented lesions through the color alone.

However, the thickness of the normal nail bed in healthy individuals was approximately $1.17 \mathrm{~mm}^{[18]}$. Histopathologically, melanocytes in nail matrix were usually found in suprabasal position between the second layer and the fourth layer; in the nail bed, all melanocytes were situated in the first and second layers ${ }^{[3,5,19]}$. Di et al. reported that the average thickness (depth) for subungual pigmented lesions was $0.08 \mathrm{~mm}$ (range, 0.04 to $0.12 \mathrm{~mm}$ ), and the thickness of subungual melanocytic nevi ranged from 0.04 to $0.07 \mathrm{~mm}$ (mean, $0.05 \mathrm{~mm}$ ) ${ }^{[20]}$. In our series, there are 5 patients with the width of the pigmented bands ranged from $1 / 4$ to $2 / 5$ of the whole nail, these five patients underwent the aesthetic repair on split-thickness excision of the pigmented nail matrix and nail bed lesions under microscope. No patients recur in a follow-up of over one year. Thus, the aesthetic repair on split-thickness excision of the pigmented nail matrix and nail bed lesions under microscope is reliable and feasible. When the width of the pigmented bands was more than $1 / 2$ of the whole nail width, the split-thickness excision of the pigmented nail matrix and nail bed lesions under microscope can lead to the nail malnutrition or deformity. Thus, the whole nail resection is an option.

The absence of nail may not only influence the appearance and function of the injured foot/hand but also give rise to a psychological burden on the patients due to the poor appearance of the toe/finger. In addition to improving the sensitivity and stability of the toe pulp, the nail also has an aesthetic effect ${ }^{[21-23]}$. To date, the attention on the 
aesthetic reconstruction of the fingernail defects continues to be paid ${ }^{[21,23,24]}$, whereas the emulational repair and aesthetic reconstruction of the toenail defects has been neglected for a long time. With the popularity of increasingly aesthetic knowledge, aesthetic reconstruction of toenail soft tissue defects possesses increasingly requirements. Therefore, the reconstruction of the toenail soft tissue defects poses a severe challenge for surgeon.

The wound repair following the resection of the whole nail is also a brainteaser. In clinical practice, skin grafts for repairing the nail soft tissue defects with phalanx exposure often presented with the hypertrophic scar at recipient site ${ }^{[16]}$. The fillet flap with the phalanx shortening often requires the sacrifice of the distal phalanx ${ }^{[15]}$. Free flap has some disadvantages of long operative time and microsurgical microvascular anastomosis ${ }^{[17]}$. Currently, few studies focus on the toe pulp flaps for reconstructing the nail defects. Cheng et al reported a lateral toe pulp flap for repairing the dorsal toe defect ${ }^{[25]}$. Tashiro et al reported a second-toe lateral hemipulp flap transfer to cover a thirdtoe pulp defect ${ }^{[26]}$. In our series, mimical reconstruction of the nail following the resection of the whole nail was performed using the lateral toe pulp island flap. All patients obtained the excellent function and aesthetic outcomes, and all patients were satisfied. The lateral toe pulp island flap provides several merits over the use of conventional flaps ${ }^{[15-17]}$, including short operation time, simple flap dissection, minimal donor site morbidities, and outstanding functional and aesthetic outcomes. In addition, the texture and color of the toe pulp is similar to that of the toenail because the toe pulp has a thicker cuticle. This flap can mimic the unique original characteristics of the toenail to minimize deformities. The toe pulp can provide a glabrous skin flap suitable for resurfacing toenail soft tissue defect, realizing sensate reconstruction via "replacing like with like".

\section{Conclusions}

Mimical reconstruction and aesthetic repair of the nail following resection of subungual melanocytic nevus is a reliable and feasible. It seems to be satisfactory that "like tissue" repairs the complex nail defects. All patients obtain an excellent aesthetic outcome.

\section{Abbreviations}

BRAF: v-raf murine sarcoma viral oncogene homolog B1

MR: Mimical reconstruction of the nail bed

AR: Aesthetic repair of the nail bed

\section{Declarations}

Ethics approval and consent to participate: The experimental protocol was established, according to the ethical guidelines of the Helsinki Declaration and was approved by the Human Ethics Committee of the second hospital of Shandong university. Written informed consent was obtained from individual or guardian participants.. Approval number:KYLL-2021LW1017.

Consent to publication: Not applicable. No informed consent was required, because the data are anonymized.

\section{Authors' contributions:}


N.Z collected the patient data. WP. X and XC. L analyzed and interpreted the patient data . SH. C and Y. H performed the operation. XC. L was a major contributor in writing the manuscript.

All authors read and approved the final manuscript.

Funding: Not applicable.

Competing Interests: The authors declare that they have no competing interests.

Availability of data and materials: The datasets used and/or analysed during the current study available from the corresponding author on reasonable request.

Source of Funding:Not applicable

Conflict of Interest:Not applicable.

Acknowledgements: The authors will thank all the colleagues of Department of foot and ankle surgery of the second hospital of Shandong University for their great help.

\section{References}

1. Damsky WE, Bosenberg M. Melanocytic nevi and melanoma: unraveling a complex relationship. Oncogene.2017; 36(42): 5771-5792. doi: 10.1038/onc.2017.189.

2. Singal A, Bisherwal K. Melanonychia: Etiology, Diagnosis, and Treatment. Indian Dermatol Online J. 2020;11(1): 1-11. doi: 10.4103/idoj.IDOJ_167_19.

3. Nevares-Pomales OW, Sarriera-Lazaro CJ, Barrera-Llaurador J, et al. Pigmented Lesions of the Nail Unit. Am J Dermatopathol. 2018; 40(11): 793-804. doi: 10.1097/DAD.0000000000001106.

4. Tosti A, Baran R, Piraccini BM, Cameli N, Fanti PA. Nail matrix nevi: a clinical and histopathologic study of twenty-two patients. J Am Acad Dermatol. 1996;34(5 Pt 1): 765-71. doi: 10.1016/s0190-9622(96)90010-9

5. Ruben BS. Pigmented lesions of the nail unit: clinical and histopathologic features. Semin Cutan Med Surg. 2010;29(3): 148-58. doi: 10.1016/j.sder.2010.06.008.

6. Rtshiladze MA, Stretch JR, Stewart DA, Saw RP. Pigmented lesions of the nail bed - Clinical assessment and biopsy. Aust Fam Physician. 2016;45(11): 810-813.

7. Di Chiacchio ND, Farias DC, Piraccini BM, et al. Consensus on melanonychia nail plate dermoscopy. An Bras Dermatol. 2013;88(2): 309-13. doi: 10.1590/S0365-05962013000200029.

8. Bevona C, Goggins W, Quinn T, Fullerton J, Tsao H. Cutaneous melanomas associated with nevi. Arch Dermatol. 2003;139(12): 1620-4; discussion 1624. doi: 10.1001/archderm.139.12.1620.

9. Lin WM, Luo S, Muzikansky A, et al. Outcome of patients with de novo versus nevus-associated melanoma. J Am Acad Dermatol. 2013;72(1): 54-8. doi: 10.1016/j.jaad.2014.09.028.

10. Haenssle HA, Mograby N, Ngassa A, et al. Association of Patient Risk Factors and Frequency of NevusAssociated Cutaneous Melanomas. JAMA Dermatol. 2016;152(3): 291-8. doi: 10.1001/jamadermatol.2015.3775.

11. Clark WH Jr, Elder DE, Guerry D 4th, Epstein MN, Greene MH, Van Horn M. A study of tumor progression: the precursor lesions of superficial spreading and nodular melanoma. Hum Pathol. 1984;15(12): 1147-65. doi: 10.1016/s0046-8177(84)80310-x. 
12. Miller AJ, Mihm MC Jr. Melanoma. N Engl J Med. 2006;355(1): 51-65. doi: 10.1056/NEJMra052166.

13. Damsky WE, Theodosakis N, Bosenberg M. Melanoma metastasis: new concepts and evolving paradigms. Oncogene.2014; 33(19): 2413-22. doi: 10.1038/onc.2013.194.

14. Braun RP, Baran R, Le Gal FA, et al. Diagnosis and management of nail pigmentations. J Am Acad Dermatol. 2007;56(5): 835-47. doi: 10.1016/j.jaad.2006.12.021.

15. Baek SO, Suh HW, Lee JY. Modified toe pulp fillet flap coverage: Better wound healing and satisfactory length preservation. Arch Plast Surg.2018; 45(1): 62-68. doi: 10.5999/aps.2017.01501

16. Liu TH, Hsieh MC, Chou PR, Huang SH. Reconstruction for Defects of Total Nail Bed and Germinal Matrix Loss with Acellular Dermal Matrix Coverage and Subsequently Skin Graft. Medicina (Kaunas).2020; 56(1):17. doi: 10.3390/medicina56010017.

17. Hong MK, Park JH, Koh SH, et al. Microsurgical Free Tissue Options for Fingertip Reconstruction. Hand Clin. 2021;37(1): 97-106. doi: 10.1016/j.hcl.2020.09.002.

18. Ferrusquia-Toriz D, Hernández-Díaz C, Amezcua-Guerra LM, et al. Ultrasound characterization of the nail bed in patients with systemic lupus erythematosus. Lupus. 2021;Apr;30(4):608-614. doi:

$10.1177 / 0961203320988609$.

19. Perrin C, Michiels JF, Pisani A, Ortonne JP. Anatomic distribution of melanocytes in normal nail unit: an immunohistochemical investigation. Am J Dermatopathol.1997; 19(5): 462-7. doi: 10.1097/00000372$199710000-00005$.

20. Di Chiacchio N, Loureiro WR, Michalany NS, Kezam Gabriel FV. Tangential Biopsy Thickness versus Lesion Depth in Longitudinal Melanonychia: A Pilot Study. Dermatol Res Pract.2012; 2012: 353864. doi: $10.1155 / 2012 / 353864$.

21. Yan H, Persons B, Gao W, Angel MF, Zhang F. Nail flaps for microsurgical aesthetic reconstruction of thumb and donor site of great toe. J Plast Surg Hand Surg. 2012;46(3-4): 212-4. doi: 10.3109/2000656X.2011.631287.

22. Mignemi ME, Unruh KP, Lee DH. Controversies in the treatment of nail bed injuries. J Hand Surg Am. 2013;38(7): 1427-30. doi: 10.1016/j.jhsa.2013.04.009.

23. Koh SH, You Y, Kim YW, et al. Long-term outcomes of nail bed reconstruction. Arch Plast Surg. 2019;46(6): 580588. doi: 10.5999/aps.2019.00997.

24. Tang JB, Elliot D, Adani R, Saint-Cyr M, Stang F. Repair and reconstruction of thumb and finger tip injuries: a global view. Clin Plast Surg. 2014;41(3): 325-59. doi: 10.1016/j.cps.2014.04.004.

25. Cheng LF, Lee JT, Wu MS. Lateral Toe Pulp Flap Used in Reconstruction of Distal Dorsal Toe Defect: Case Report and Review of the Literature. Ann Plast Surg.2019; 82(1S Suppl 1): S136-S139. doi: 10.1097/SAP.0000000000001703.

26. Tashiro K, Narushima M, Yamamoto T, lida T, Koshima I. Second toe lateral hemipulp flap transfer to cover third toe pulp defect. J Plast Reconstr Aesthet Surg. 2014;67(4): e120-1. doi: 10.1016/j.bjps.2013.11.007.

\section{Figures}



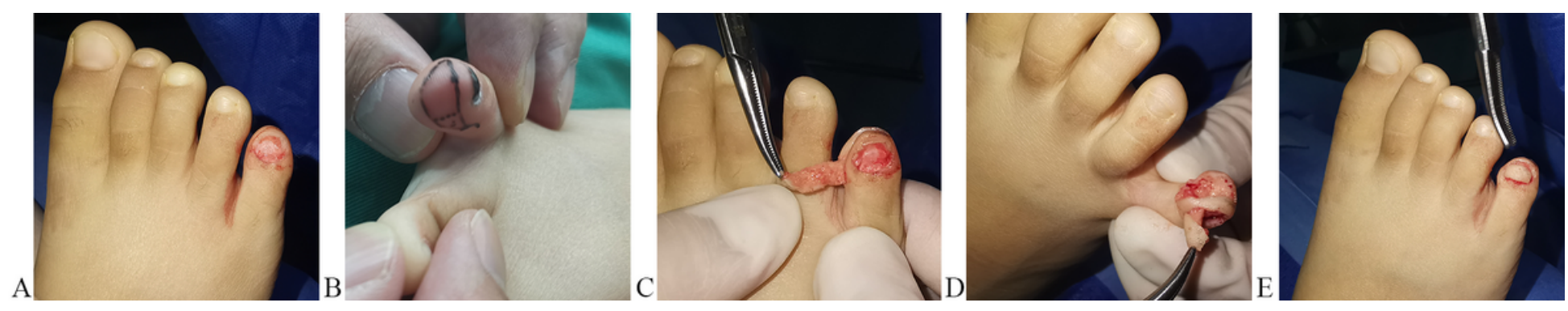

\section{Figure 1}

The surgical procedure of mimical reconstruction of the nail. (A) removing nail plate and resecting the whole nail bed and matrix, (B) Lateral toe pulp island flap design, (C) Flap dissection, (D) The flap was transferred to the defect region of the nail bed via the subcutaneous channel, (E) The flap covered the wound.
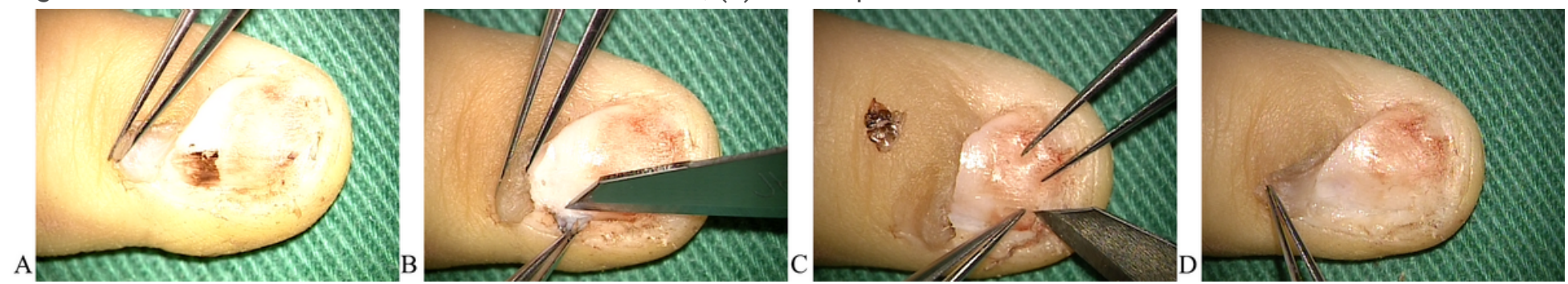

\section{Figure 2}

The surgical procedure of aesthetic repair of the nail. (A) Longitudinal incision, (B and C) Split-thickness excision procedure of the pigmented nail matrix and nail bed lesions under microscope, (D) The residual nail matrix and nail bed was flatted under microscope.

A
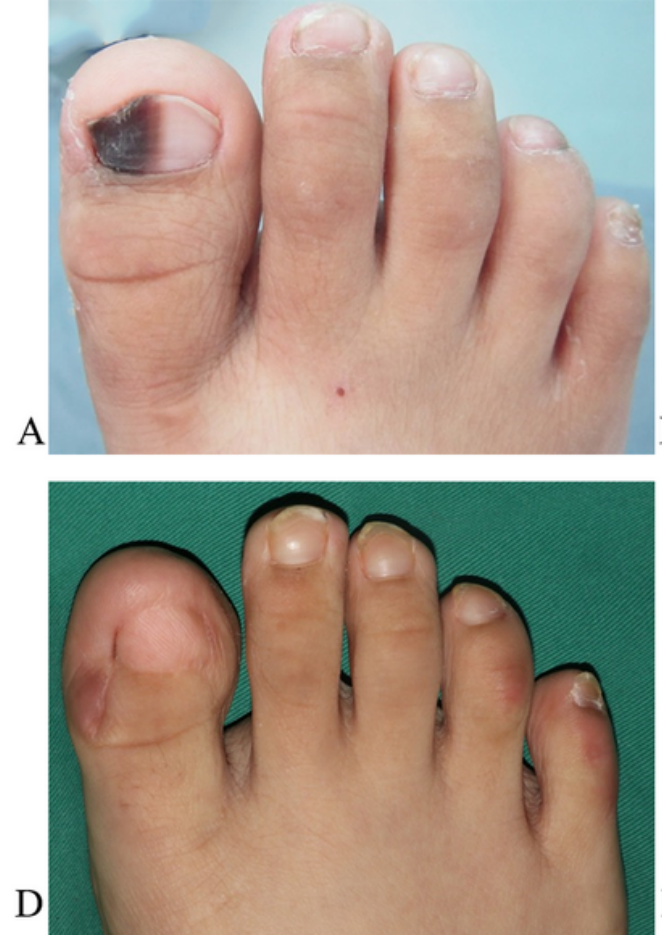

$\mathrm{B}$

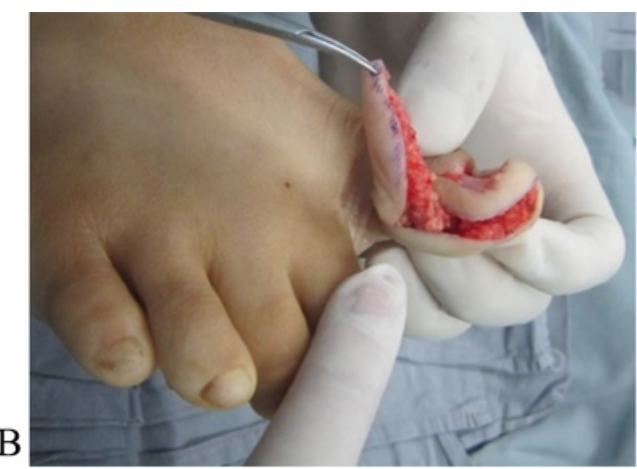

$\mathrm{E}$

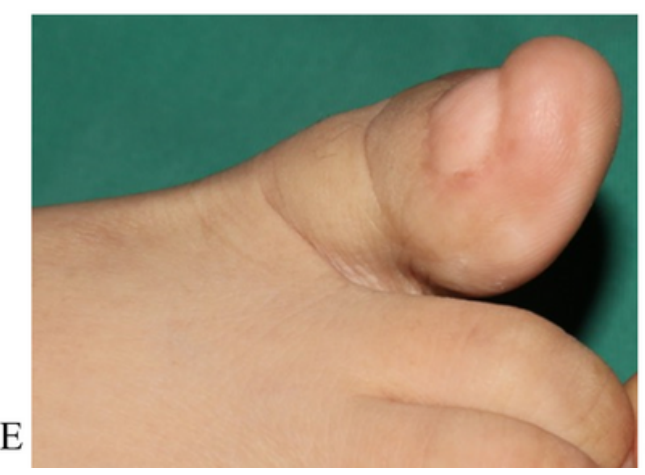

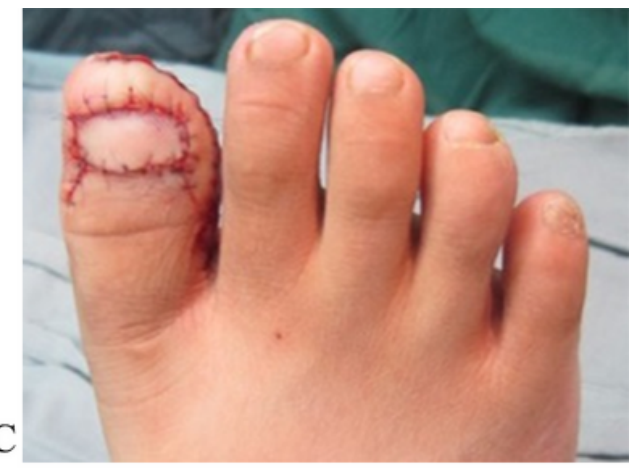

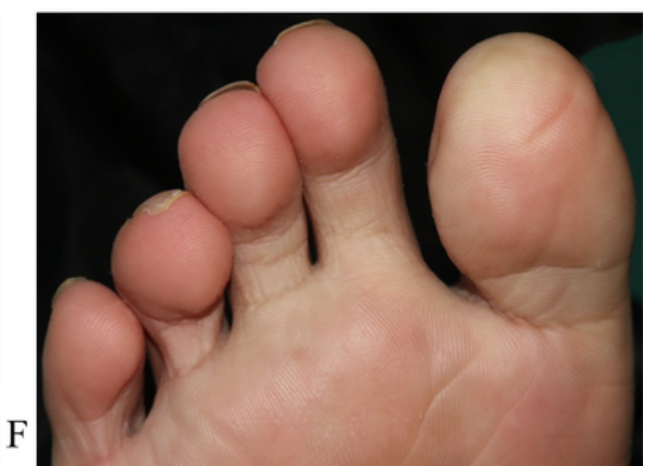

Figure 3 
The pre-, intra- and post-operative results of case 1. (A) Subungual melanocytic nevus of hallux of right foot. (B and C) The defect of the nail matrix after the resection of tumor was repaired with the lateral toe pulp island flap based on the plantar digital artery. (D, E and F) The result after 16 months.
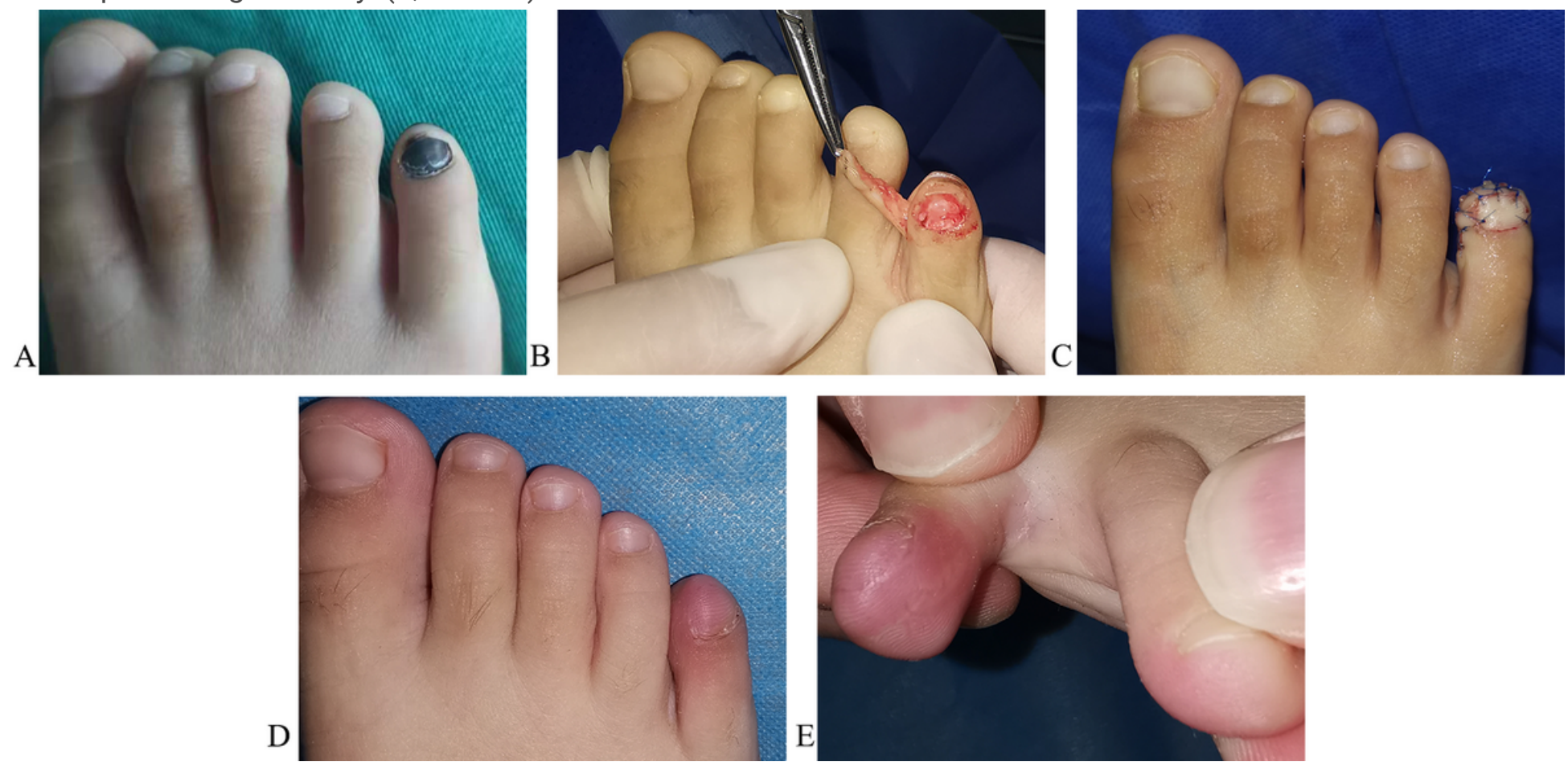

\section{Figure 4}

The pre-, intra- and post-operative results of case 2. (A) subungual melanocytic nevus of the fifth toe of right foot. (B and $C$ ) the defect of the nail matrix after the resection of tumor was repaired with the lateral toe pulp island flap based on the plantar digital artery. (D and $E$ ) the result after 5 months.

A
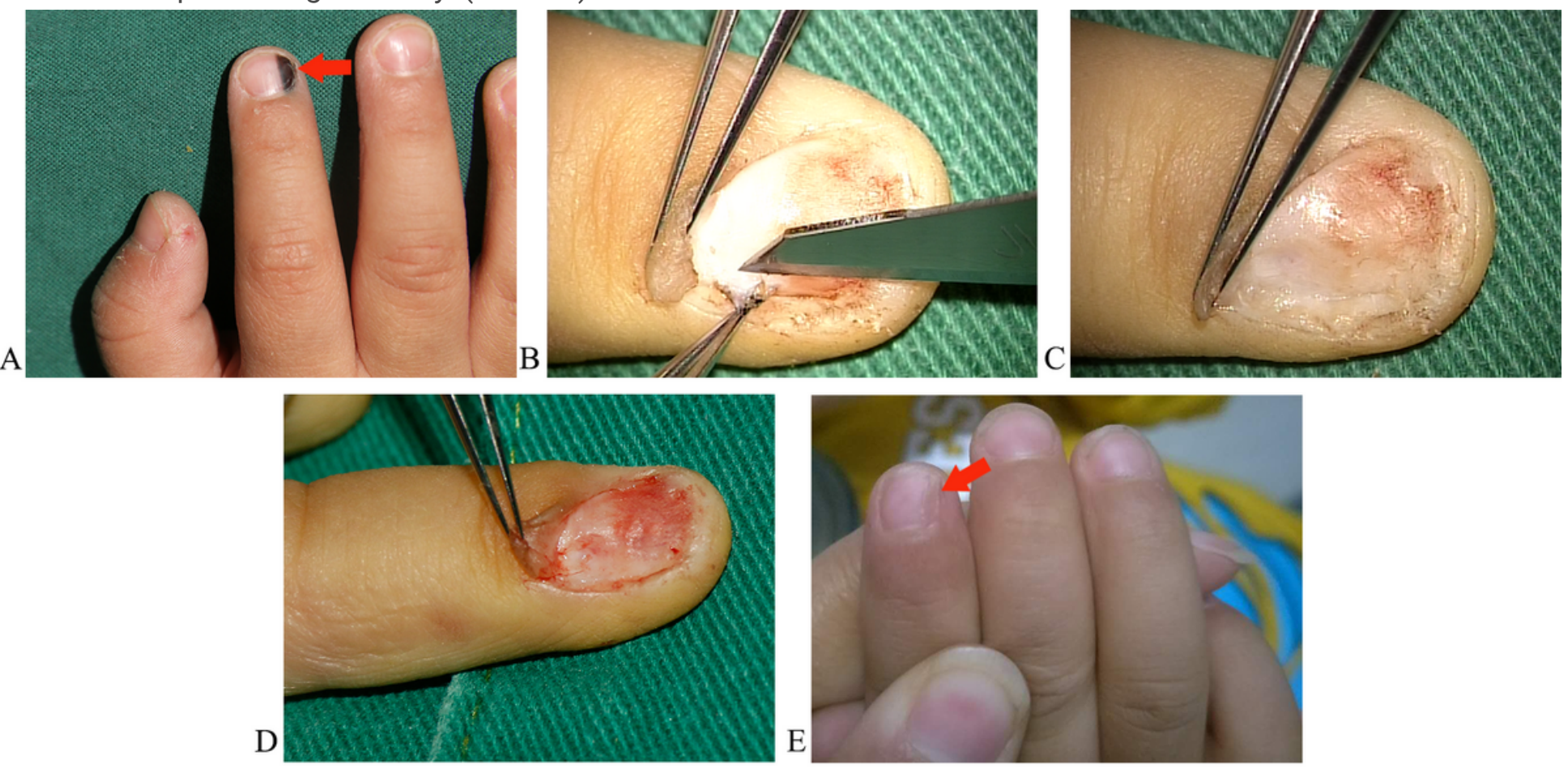

Figure 5 
The pre-, intra-, and post-operative results of case 3. (A) subungual melanocytic nevus of the index finger of the right hand. (B and $C$ ) the split-thickness excision of the pigmented nail bed lesions under microscope. (D) the residual nail bed was flatted. (E) the result after 20 months. 